\title{
Consciousness Binds Consciousness Releases
}

\author{
Aju Mukhopadhyay \\ Poet, Critic and Author \\ India \\ ajum24@gmail.com
}

\begin{abstract}
Consciousness is one which pervades the whole existence; from material to vital and mental world and beyond. Not only mind or its awareness, nor matter nor senses alone; every being, everything is replete with consciousness. Consciousness as an element may rise high above that psychological stratum to which we give the name of mentality. There is a super conscient stage as well as subconscient. Endowed with mind man is most miserable as he cannot avoid fear and anxiety but he has no clue to control his miseries. The human being is used to collective consciousness which safely guides animals without a tormenting mind but it pulls man down. Collective thought, collective suggestions are formidable influences which act constantly on individual thought with mixture of obscurities and unconsciousness. One needs to be established on his individuality.

It is only with this spiritual capacity of rising to a higher level and replacing the animal's unconsciousness by a spiritual super-consciousness that man can see the goal of existence, foresee the culmination of his efforts and have a clear-sighted trust in a higher spiritual power to which one can surrender one's whole being. Spirituality is in its essence an awakening to the inner reality of our being, to a spirit, self, soul which is other than our mind,
\end{abstract}


life and body. Spiritual consciousness releases humanity from all pitfalls. Spiritualism has been in practice in India and elsewhere by the exponents of it from the ancient time. Besides the masters of it which are too less in modern world some clever people have come to acquire snippets of this vast discipline and use them professionally for the benefit of different groups including themselves in this digital age. The high-tech Gurus through piecemeal application of the science and art of spiritualism make it vehicle of commerce for their own benefit. They are dangerous to the society.

Keywords: Consciousness, Collective consciousness, Superconscient, Subconscient, Spirituality, High-tech Guru

\section{Consciousness}

Consciousness is one which pervades the whole existence; from material to vital and mental world and beyond. Not only mind or its awareness, nor matter nor senses alone; every being, everything is replete with consciousness. Everything is conscious, from stone to human being, at different levels. Consciousness is an inner space. Sri Ramana Maharshi conceived consciousness as a force behind every object and living form. He identified it as the Self, the Atma, absolute silence. Ordinary consciousness is awareness through intellect, mind and senses. Cosmic consciousness is beyond them. It is awareness at the universal level; universal matter, energy, mind and forces. Spiritual consciousness is awareness of Self, Spirit and the Divine.

Sachchidananda (Existence, Consciousness, Bliss) is usually conceived as the highest state of consciousness. But Supramental consciousness is the next state of consciousness as realised by Sri Aurobindo; its descent took place in his body and Mother worked with it till her 
last days of physical existence on earth, transforming her body to the extent possible. Sri Aurobindo said that there are further heights, not yet explored.

Space as we know is outer space and consciousness is inner space. Nachiketas's journey through the inner space freed him from stain and death by the realisation of God (Katha Upanishad).

Referring to Sir Jagadish Chandra Bose's findings in plants and metals Sri Aurobindo observed in The Life Divine "There is a superconscient in us as well as subconscient, a range of conscious faculties and therefore an organisation of consciousness which rise high above that psychological stratum to which we give the name of mentality. And since the subliminal self in us thus rises in superconscience above mentality, may it not also sink in subconscience below mentality? ... . If so, we must suppose in the plant and the metal also a force to which we can give the name of consciousness ....

"The seeking and shrinking of the plant, its pleasure and pain, its sleep and its wakefulness and all that strange life whose truth an Indian scientist has brought to light by rigidly scientific methods, are all movements of consciousness ....

"Mind and Matter are rather different grades of the same energy, different organisations of one conscious Force of Existence.” (Divine 18/ 86-88)

\section{Ordinary Consciousness Binds Spiritual Consciousness Releases}

Mother comes out with all her experiences and spiritual resources to observe that the 'Miserable man' suffers for being endowed with mind, thus possessing mental consciousness which makes him fastidious, nervous and fearful; always thinking about the catastrophic future, making a hill out of a mole.

"With man there has begun this perpetual worrying about what is going to happen, and this worry is the principal, if not the sole cause of his torment. With this objectivising 
consciousness there has begun anxiety, painful imaginations, worry, torment, anticipation of future catastrophes, with the result that most men- and not the least conscious, the most conscious- live in perpetual torment. Man is too conscious to be indifferent, he is not conscious enough to know what will happen. Truly it could be said without fear of making a mistake that of all earth's creatures he is the most miserable. The human being is used to being like that because it is an atavistic state which he has inherited from his ancestors, but it is truly a miserable condition." (Mother $9 / 303$ )

"Truly speaking there is no condition more miserable than being responsible for an existence to which one doesn't have the key, that is, of which one doesn't have the threads that can guide and solve the problems." (Mother $9 / 304)$

And here she compares man the superior animal with animal proper. Animals are saved for being inferior to man.

"The animal sets itself no problems: it just lives. Its instinct drives it, it relies on a collective consciousness which has an intimate knowledge and is higher than itself, but it is automatic, spontaneous, it has no need to will something and make an effort to bring it about, it is quite naturally like that, and as it is not responsible for its life, it does not worry." (Mother 9/304)

During another discussion she tells how man, instead of becoming concerned with his individuality becomes a victim of collective consciousness as a species but this collective consciousness is not exactly the same as that of the animals. Here we find another point added by Mother. It is that of exchange between individuals and groups with strong and abiding suggestions; constant mental and vital exchanges without being aware of it, accepting it as a matter of course.

"You must also understand that you are not separate individualities, that life is a constant exchange of forces, of consciousness, of vibrations, of movements of all kinds. It is 
as in a crowd, you see; when everyone pushes all go forward, and when all recedes everyone recedes. It is the same thing in the inner world, in your consciousness. There are all the time forces and influences acting and reacting upon you, it is like a gas in the atmosphere, and unless you are quite awake, these things enter into you, and it is only when they have gone well in and come out as if they come from you, that you become aware of them .... And those very quiet people, not at all wicked, who suddenly become furious when they are in a furious crowd! And no one knows who has started it: it is something that went past and swept off the consciousness. There are people who can let out vibrations like this and others respond without knowing why. Everything is like that, from the smallest to the biggest things.

"You are moved by all kinds of things, without taking any note of it at all. Collective thought, collective suggestions are formidable influences which act constantly on individual thought. And what extraordinary is that one does not notice it. . . There is a mixture of obscurities, a mixture of unconsciousness, and inevitably you slip into this unconsciousness. (Mother 4/ 35-36) To overcome the situation she tells us to come out of such collective consciousness and regain our individuality, to avoid becoming a victim of mass mania, of constant influences of various kinds.

"To escape this there is but one means: to become conscious of oneself, more and more conscious and more and more attentive ... .

"To be individualised in a collectivity, one must be absolutely conscious of oneself. And of which self? - the Self which is above all intermixture, that is, what I call the Truth of your being.

"It is thus that gradually, slowly, with perseverance, first of all with great care and much attention, one becomes conscious, learns to know oneself and then to become master of oneself." ( Mother 4/ 36-37) 
By nature some people are strong in the vital and mental makeup; they are individuals though too rigid sometimes. It helps and at the same time bars their progress. But they are as they are. Man is endowed with higher consciousness by the Divine to help him rise above animality, gain his true individuality and make progress.

"Consciousness has been given to man so that he can progress, can discover what he doesn't know, develop into what he has not yet become, and so it may be said that there is a higher state than that of an immobile and static peace: it is a trust total enough for one to keep the will to progress, to preserve the effort for progress while ridding it of all anxiety, all care for results and consequences.

"The next step is to face the problem, but with the calm and certitude of an absolute trust in the supreme power which knows, and can make you act. And then, instead of abandoning action, one can act in a higher peace that is strong and dynamic." (Mother 9 /305)

But for this, Mother asks man to avail the fount of his spiritual resources by surrendering to the Divine, the most potent action in Sri Aurobindo's Integral Yoga.

"And it is only with this spiritual capacity of rising to a higher level and replacing the animal's unconsciousness by a spiritual super-consciousness that there comes into the being not only the capacity to see the goal of existence and to foresee the culmination of the effort but also a clear-sighted trust in a higher spiritual power to which one can surrender one's whole being, entrust oneself, give the responsibility for one's life and future and so abandon all worries." (Mother 9/303-04)

She calls this to be a new way of success, an achievement through spiritual realisation while remaining in spiritual consciousness.

"This is what could be called a new aspect of the divine intervention in life, a new form of intervention of the divine forces in existence, a new aspect of spiritual realisation." (Mother 9 1305) 


\section{Pioneers in the field of Consciousness}

The words like consciousness and spirituality are often heard but used for purposes which do not connote full sense or accurate meaning. Stream of consciousness does not carry the exact idea. Spirituality is not an elevated thinking, aesthetic living or anything highly ethical or moral. They are good in their own places but not spiritual in essence. When we hear or find the word consciousness the faces that flash first in our mind's sky are of Sri Aurobindo and the Mother. As they dwelt on, experimented with and applied higher consciousness in their lives and conferred most on the subject: consciousness. They reached the confluence of vast numbers of cultures and languages of the world with commanding positions.

\section{Sri Aurobindo}

Sri Aurobindo was master of Thoughts and Ideas; a journalist, poet, essayist and author of volumes of books. He mastered some half a dozen Indian languages including Sanskrit and Vedic after coming to India and settling in Baroda as he had mastered similar numbers of European languages including Latin and Greek while living in England. He was the fount of many-hued culture. Satprem's biography of Sri Aurobindo is titled Sri Aurobindo or the Adventure of Consciousness. Sri Aurobindo rediscovered consciousness in modern terms. His spiritual expeditions were in the realms of consciousness. He analysed the subtle nuances of it. Sri Aurobindo and Spirituality are synonymous.

\section{The Mother}

Both the parents of the Mother were of Sephardic Jewish origin; Mother's father, Maurice Alfassa was a banker from Adrianople and her mother, Mathilde Ismalun was from Alexandria. She was a descendant of the family of Egyptian Pharaoh. In those days Alexandria was the most cosmopolitan city. There was full amity among the Arabs, Jews, Egyptians, 
Syrians, Lebanese and Italians. Maurice Alfassa and Mathilde Ismalun were married at Alexandria. When Mirra (The Mother) was born in Paris in 1868, Mirra and Mira were the short forms of the Hebrew name Miriam. She was named Mirra Alfassa. Her devotees later found MA in her name pronounced as Ma meaning mother in most Indian languages; Mother was a universal Mother from her birth.

There was admixtures of all cultures at the place and time of her birth. She had many extraordinary experiences during her childhood which were occult, beyond the reach of a materialist. She beheld pages of books transparent with different and accurate history other than what was written there. Beginning her Yoga from the age of four without knowing, she had series of occult, spiritual experiences. To learn occultism she remained in Algeria for some time. Moving in many European countries she came to India to meet Sri Aurobindo and remained forever near him in Pondicherry but in between her meetings with him she travelled and stayed for some years in Japan and visited China. Everywhere she worked and had ever new experiences. She inherited and cultivated a myriad culture before she took her seat as the Mother of Sri Aurobindo Ashram in Pondicherry, India. She practised and experienced the work of Supramental consciousness in her body which was first manifested in Sri Aurobindo's body. Sri Aurobindo and the Mother were the exponents of Consciousness

\section{Religion}

When we talk of consciousness and spirituality we have to remember that most devout persons live with their respective religions. Though its aim is spirituality it is dwarfed by man's ordinary consciousness. The position of religion is as below.

Thirst for beyond and glimpse of it gave birth to religion. It was later distorted with all rules and narrow separatism so much that most religionists forgetting the essential humility in such matters felt that their religion was superior to the others and hence they quarreled and 
fought with each other. Some people of one of the ultra religions aim at eliminating all other religions violently as they do not adhere to their faith. Ruinous bestiality was being perpetrated by them jeopardizing the global life. Mother of Pondicherry always condemned religions and spoke in favour of spiritualism. The opposite of spiritualism is materialism. Religion is in between them. Religion gets rusted through superstition so great people have advised to go beyond religion embracing spirituality which is finer and wider than rules and regulations. This is not to deny that the age old spiritual practices included religions rituals. The truth of pure religion remains.

Sri Aurobindo asserted that, "Spirituality is much wider than any particular religion, and in the larger ideas of it that are now coming on us even the greatest religion becomes no more than a broad sect or branch of the one universal religion". (Culture 427)

\section{Material attitude to life and God}

We must remember that apart from consciousness, religion and spirituality the basic concept of the world is matter giving birth to a materialistic outlook. With matter we begin though we do not end there. But there are large numbers of people who deny the other aspects of life and find all within the boundaries of matter. It is their way and we must respect differing ways of different people.

Materialists are mostly atheists. Atheists deny the reign of religion. And in between theist and atheist are the agnostics who do not matter much. Materialism stands as a contrast to spiritualism. Communism is the best example of materialism. We have the direct experience of how the communist world butchered millions of men to establish the right of the proletariats but in the process millions of proletariats were ruined and only Dictators surfaced. The inner stories of communist movements have been written by competent writers. Communism has changed faces in countries infected by it but it has been banished from most of them. It is 
awaiting its further banishment. In the 1960s Existentialism came to possess the intellect of some people. It was a complete negative idea about human life. As a movement Existentialism has lost its footing.

\section{Spirituality}

Spiritualism is a faith on existence beyond what we see before our nose and a humility that I and my knowledge are not the end of the world, that there are vast things which I have yet to grasp and know, that my past and future neither were nor are fixed. Guessed by intuition and verified by experiment man conceives that there are phenomena beyond reasonable explanation. And accordingly he believes in the beyond with faith on something like God.

India has given birth to large numbers of great Rishis and Munis who uttered the highest words of wisdom through Vedas and Upanishads as heard and realised by them. India is the birth place of some great religions."Indian culture has been from the beginning and has remained a spiritual, an inward-looking religio-philosophical culture," Sri Aurobindo said. (Culture 52)

Yogi Sri Aurobindo realised that "Spirituality is in its essence an awakening to the inner reality of our being, to a spirit, self, soul which is other than our mind, life and body, an inner aspiration to know, to feel, to be that, to enter into contact with the greater Reality beyond and pervading the universe which inhabits also our own being, to be in communion with It and union with It, and a turning, a conversion, a transformation of our whole being as a result of the aspiration, the contact, the union, a growth or waking into a new becoming or new being, a new self, a new nature." (Divine /19/857)

For the progression from mundane to the spiritual, to establish divine life on earth he depended entirely on spiritualism, "To discover the spiritual being in himself is the main business of the spiritual man and to help others towards the same evolution is his real service 
to the race ... an outward help could succor and alleviate, but nothing or very little more is possible." (Divine 19/884-85)

In his The Ideal of Human Unity Sri Aurobindo stressed that the ultimate union between the nations would be possible through spiritual means and that would be in a spiritual age but, "The spiritual age will be ready to set in when the common mind of man begins to be alive to these truths and to be moved or desire to be moved by this triple or triune Spirit." (Unity 244) Swami Vivekananda's poems are examples of his spiritual realization; vibrant, ever living poems are expressed in simple and direct poetic utterances. His poems exude peace and spiritual confidence. He realises God everywhere in Nature; immanent: I feel Him standing by Over hill and dale, high mount and vale,

Far away and high

Vivekananda In Search of God /Other Poems 4 He feels God nowhere else than in himself. Repeating Shankaracharya's words that the world is a dream, a Maya, he tells in the same breath that it is True; God is the truth, living in him.

This world's a dream Though true it seem.

And only Truth is He the living!

The real me is none but $\mathrm{He}$

And never never matter changing!

Vivekananda My Play is done /Other Poems 9

\section{Delight of true Spiritual Life}

Surmounting all obstacles true spiritual consciousness, above all other consciousness, releases humanity from all pitfalls. Let us hear the charm of spiritual life as Sri Aurobindo tells us: "The delight of the Spirit is ever new, the forms of beauty it takes innumerable, its godhead ever young and the taste of delight, rasa, of the Infinite eternal and inexhaustible." (Divine /19/1069) 


\section{Merchants of Spirituality}

Spiritualism has been in practice in India and elsewhere by the exponents of it from the ancient time. Except the masters of it some modern clever people have come to acquire snippets of this vast discipline and use them for the benefit of different groups of people including themselves in this digital age. They are professionals; they practice spirituality. The high-tech Gurus through piecemeal application of the science and art of spiritualism make it vehicle of commerce for their own benefit. This does not fulfill the spiritual thirst or attainment of it. They are dangers to true spirituality. Some of them are caught for the crude practices of their ill conceived knowledge and are publicly punished.

A newspaper reports, "If we go by ancient lore, enlightenment waits only at the end of a long and arduous path. It is obviously not available in spiritual supermarkets at the flash of a credit card ....

"However, New Age in India is still largely an urban westernised phenomenon. Curiously enough, the urban elite have discovered Indian spirituality through the distilled versions available from the west. ..."1

Large numbers of Doordarshan channels are used for this purpose. Some of the Gurus are caught for their misdeeds and others flourish in business. Some of the followers of the past Gurus continue to run their organisations with commercial motive as the vacant places of the Gurus remain vacant. There is no wrong if snippets of ancient wisdom are used to benefit some but it is usually bereft of spirituality except for some individuals who may continue to practice it on their own. Often the running of many such organizations is not clean. Along with this some intellectuals propagate the teachings and lives of great spiritual personalities with their limited resources, in their limited circles and groups. In most cases such amateurs other than getting themselves puffed up help neither the aspirants nor the past Gurus. Spiritualism is a 
systematic and time consuming effort. For a real success most of them should have received a call from the beyond.

\section{Notes}

"Merchants of Nirvana" in the Sunday Chronicle, Chennai, dated 31.7.2005 


\section{References}

Sri Aurobindo. The Life Divine. V.18 and 19. Pondicherry: SABCL; Sri Aurobindo Ashram. 1970. Hardbound.

Collected Works of The Mother-Centenary Edition. The Mother. Pondicherry: Sri Aurobindo Ashram. V.9. 1977. Hardbound.

The Mother. Pondicherry: Sri Aurobindo Ashram. V.4. 1972. Hardbound.

Sri Aurobindo. The Foundations of Indian Culture. Pondicherry: SABCL; Sri Aurobindo Ashram. 1972. V.14. Hardbound.

Sri Aurobindo. The Ideal of Human Unity. Pondicherry: SABCL; Sri Aurobindo Ashram. 1972. V. 15. Hardbound.

Swami Vivekananda. In Search of God and other Poems. Kolkata: Advaita Ashram. 2009. Paperback. 